\title{
Menuet v české lidové hudbě: analýza a hudební typ
}

Zdeněk Vejvoda

DOI: 10.21104/CL.2016.4.04

Minuet in the folk music: analysis and the musical type

Abstract The long-term research of the characteristics of Czech folk dance melodies reveald that the songs and instrumental melodies from the collections from the 19th and 20th centuries be divided into several distinct musical groups. Besides the already described types of triple meter, "round and round", ,"ändler", "mazurka" or polonaise-like rytmical.melodical structures there is also a distinctive musical type, minet or folk minuet. The present study aims to confirm the subjectively perceived musical quality of Czech minets through the method of computer structural analysis and to present them in the context of so far published historical researches and musicological analyses.
Keywords minuet, folk music, folk dance, structural analysis, complex musical analysis.

Příspěvek byl zpracován s institucionální podporou Etnologického ústavu AV ČR, v. v. i., RVO:68378076.

Contact PhDr. Zdeněk Vejvoda, Ph.D., Etnologický ústav AV ČR, v. v. i., Na Florenci 1420/3, 11000 Praha 1; e-mail: vejvoda@eu.cas.cz.

Jak citovat/How to cite Vejvoda, Zdeněk. (2016). Menuet v české lidové hudbě: analýza a hudební typ. Český lid 103, 597-622. doi:http:// dx.doi.org/10.21104/CL.2016.4.04 


\section{Původ menuetu}

Menuet je původně francouzský tanec ${ }^{1}$ třídobého metra s doloženými předchůdci z 16. století (branle a mener - srov. Trojan 1997: 547), který se po polovině 17. století stal evropským společenským a kulturním fenoménem. Podle dostupných pramenů jej poprvé tančil ve Versailles roku 1653 francouzský král Ludvík XIV. (1638-1715) na hudbu Jean-Baptisty Lullyho (1633-1687). Z francouzského dvorského prostředí tanec postupně pronikal do dalších evropských zemí. Vyznačoval se galantními figurami a prováděl se párově v řadách, později též jako tzv. kadrila (čtverylka). Zprvu hybnější tempo se v 18. století částečně zvolnilo, pohyb v osminových hodnotách ustoupil čtvrtovému. Nejstarší menuety byly dvoudílné ve 3/4 taktu, přičemž se oba díly opakovaly. Pro melodiku a hudební formu byla typická pravidelnost a symetrie. Charakteristickým se stal menuet s triem, často ve stejnojmenné mollové tónině. Kromě „užitkové“ společenské i folklorní taneční produkce menuet trvale ovlivnil i sféru evropské artificiální hudby. ${ }^{2}$

České kulturní prostředí reflektovalo menuet velmi brzy, již od konce 17. století (Pavel Josef Vejvanovský, Kristián Hirschmentzel, František Antonín Míča, Josef Schreier). Širokou oblibu menuetu v české hudbě 18. století dokládají skladby Jakuba Valeriána Pause, Františka Xavera Duška či Jana Nepomuka Augustina Vitáska. Z autorů působících v emigraci pěstovali menuet Josef Mysliveček a Leopold Koželuh, v první polovině 19. století první vlna jeho obliby doznívá u Bedřicha Diviše Webera. ${ }^{3}$

1 "Jeho název je odvozen od drobných ozdobných krůčků menus pas,

které byly pro tanec charakteristické." (Suchý 1955: 210)

2 Již první skladatel společenských menuetů Jean-Baptiste Lully uvedl tento hudebně-taneční typ do opery, na sklonku 17. století proniká menuet do suity. Ve variační podobě jako Menuet I, II (double) se tanec často objevuje u Johanna Sebastiana Bacha. Významnou roli hraje v neapolské operní sinfonii u Alessandra Scarlattiho. Mannheimští symfonikové v čele s Janem Václavem Stamicem zařadili menuet jako třetí větu do konstituující se symfonie, u Josepha Haydna se ocitá na třetím, popř. na druhém místě cyklické formy. Wolfgang Amadeus Mozart ustaluje typ čtyřvěté symfonie s třetí menuetovou částí. Na začlenění menuetu do cyklických forem působila i praxe provozování kasací, divertiment a serenád. Pro Ludwiga van Beethovena i pozdější autory představoval prostředek k navození dojmu idylicky konzervativního tance. Ve 20. století (Maurice Ravel, Sergej Prokofjev) menuet ožívá v tvorbě novoklasického zaměření (srov. Trojan 1997). Blíže k původu menuetu srov. Kazárová 2005.

Množství menuetů bylo v českých zemích komponováno k pedagogickým účelům (Jan Nepomuk Filcík: Housli škola). Shodou okolností jednou z prvních orchestrálních skladeb Bedřicha Smetany je Menuet z roku 1842. Jako výraz starodávné intimity zařazoval menuet do své instrumentální tvorby i Antonín Dvořák (Maličkosti, Serenáda pro dechové nástroje). V novoklasické produkci je někdy menuet spojován se soudobými tanečními typy (Pavel Bořkovec). 


\section{Český minet ${ }^{4}$ - přehled pramenů}

Podobně jako jinde v Evropě i v českých zemích menuet postupně zlidověl a rozšíril se v městském i venkovském prostředí. ${ }^{5}$ Podle Jana Trojana (1997: 548) „Z importovaných tanců to byl právě menuet, kterýv největší míre ovlivnil českou lidovou píseň a hudbu. [...] Pronikal do kramářských nápěvů, do salonní produkce i do chrámového provozu (preludování „slad'ounkých menuetü“ při $m s ̌ i)$ “. U zdomácnělého menuetu lze sledovat příznačné rysy, jako houpavou melodiku, jadrný rytmus a někdy i pastorální tón.

Jak dokládá Daniela Stavělová (2007: 561), byl názvem minet v lidovém prostředí již v 18. století označován jednak zdomácnělý francouzský menuet, jednak šlo o souhrnný název pro různé lidové tance stylu francouzského menuetu blízké, vyskytující se také pod jinými názvy (nabíhaná, zpáteční polonéza). $\mathrm{V}$ písemných pramenech bývá rovněž nazýván sedlskej minet, staročeský minet, francouzské minue apod. V některých dalších názvech se projevuje snaha po vystižení charakteru tance: válený minet vyjadřuje blízkost s tanečním stylem valčíku, couravá nebo loudavá vystihuje pomalý spád tance. ${ }^{6}$

Nejstarší dochované notace zlidovělého menuetu v českých zemích jsou součástí kapelnického rukopisného archivu učitele Jiř́ího Hartla (1781-1849) ze Staré Paky v Podkrkonoší. Jedná se o sérii tří „da capo“ menuetů s triem, s vročením 1811 (č. 29-31), a samostatný, rovněž trojdílný menuet, datovaný 1816 (č. 450). Jedná se o instrumentální party prvních houslí stř̌ední náročnosti.

Několik zápisů lidových menuetů pochází z první čtvrtiny 19. století, z období tzv. guberniální sběratelské akce (1819). Jsou dokladem obliby tance na českém venkově v druhé polovině 18. století. Pocházejí ze západních (Plzeňsko, Klatovsko), jižních (Prácheňsko, Budějovicko), středních a východních Čech (Kouřimsko, Čáslavsko, Nymbursko). Identické záznamy i blízké varianty se v dochovaných rukopisných i tištěných pramenech (Kolovratský rukopis, výbor T. A. Kunze, Rittersberkova sbírka, rukopis ze Sadské) různě opakují, doplňují a prolínají. Do analýzy byl zařazen soubor dvanácti tanečních písní a čtyř instrumentálních melodií.

4 V Čechách je toto označení - snad přejaté z italského minuetto - doloženo již kolem roku 1720; později proniká i do lidového prostředí (Trojan 1997: 548).

5 Svatopluk Šebek (1959: 142) uvádí: Když koncem 18. století vyvanul ze šlechtických salonů parfém menuetů, chopil se jich náš lid a přetvořil je v minety, v nichž uchoval pohybovou jemnost jejich předchůdců a zbavil je navíc škrobené vyumělkovanosti.“

6 Menuet se v lidovém prostředí rozšířil také na Moravě, cenné jsou zejména Bartošovy záznamy stylizované na způsob kantorské hudby s kontinuem (Bartoš - Janáček 1901), množství menuetů, zejména z oblasti Českomoravské vysočiny, se nachází i v tzv. Guberniální sbírce (Vetterl - Hrabalová 1994). Menuety pro nejrůznější obsazení tvořily i součást repertoáru pro domácké muzicírování (sbírka zámku Strážnice). K otázce přijetí menuetu v českém prostředí dále srov. Gremlicová 2014: 118-128. 

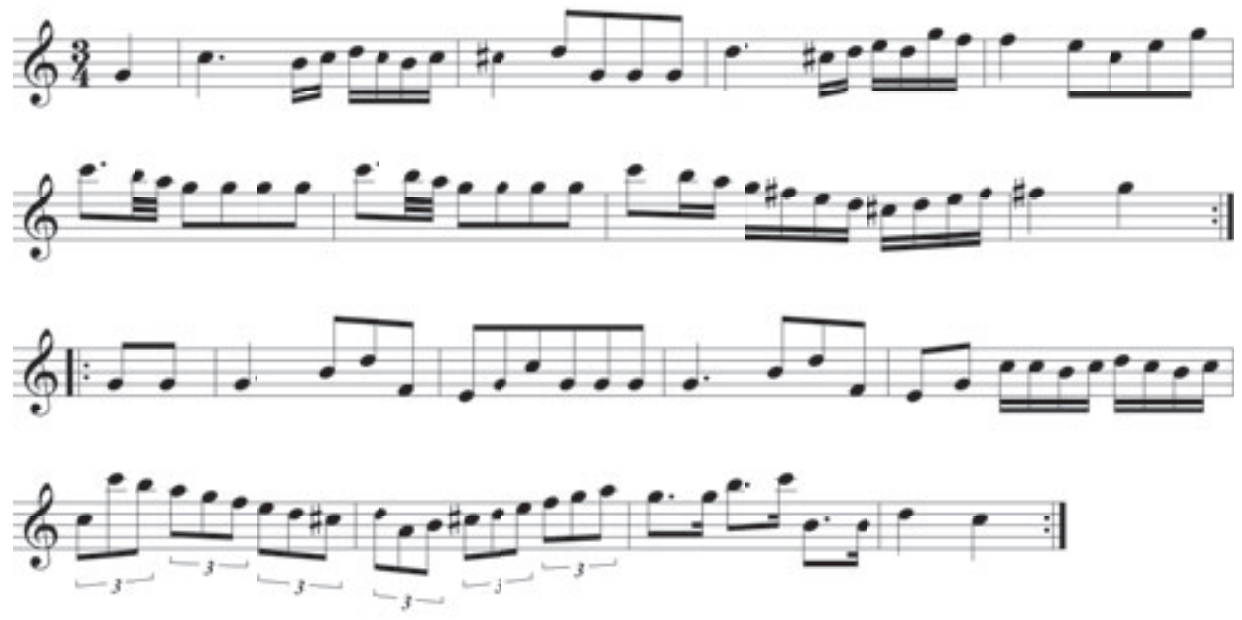

Př́klad 1 J. Hartl (1810-1822), menuetto č. 29 - 1. část; záznam 1811
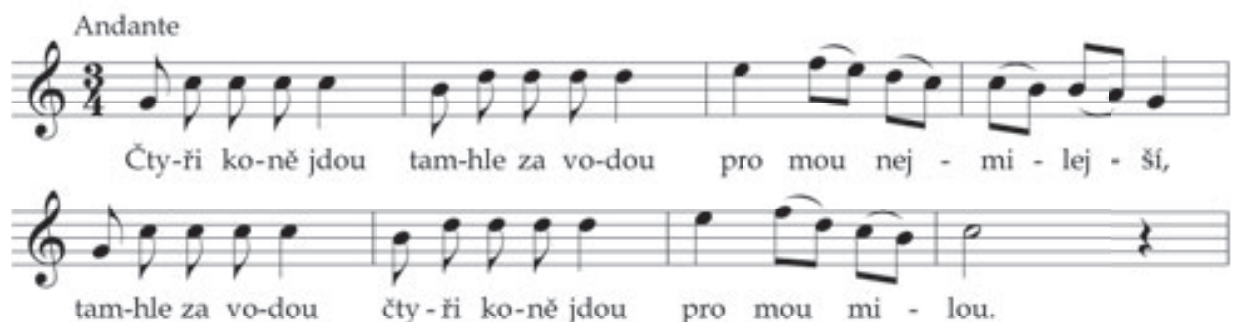

tam-hle za vo-dou čty-ři ko-ně jdou pro mou mi - lou.
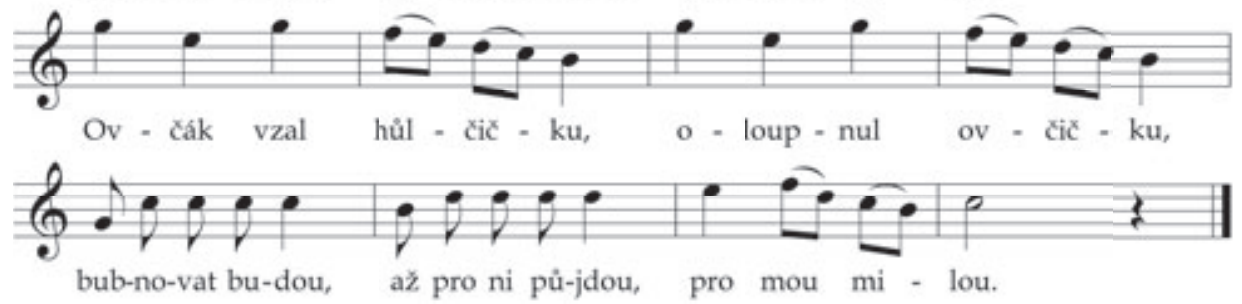

Př́klad 2 Kolovratský rukopis (ed. Markl 1987), menuet č. 13; záznam 1819

Taneční píseň s nadpisem Minet (Menuetto) starý s textovým incipitem Dej nám Pámbů zdraví $v$ tomto našem krajī otevírá první díl sbírky Václava Krolmuse Staročeské pověsti, zpěvy, hry, obyčeje, slavnosti a nápěvy z roku 1845. Sběratel v poznámce uvádí, že „,tato píseň jest pozdravení Staročechů, již při hudbě o posvícení a o svatbách na kř́ž čili na kosú, mužský s ženskou

7 Shodný textový incipit Dej nám Pán Bůh zdraví uvádí rovněž Jan Evangelista Konopas jako minet ve svém soupisu tanců z Mladoboleslavska ze 40.-70. let 19. století (srov. Stavělová 1993). Rovněž v Krolmusově seznamu tanců uveřejněném v Lumíru (2. ročník, 1852, s. 286) je na prvním místě jmenován stejný minet. 
vážně proti sobě kráčejíce, nejprvši tanec počnou zpívati a silně tancovati na vesnicích i v městečkách ještě okolo roku 1809. “Stejná píseň (s nadpisem minet starý) je uvedena i v notované př́loze písní z Krolmusovy sbírky v úpravě pro klavír a zpěv od Josefa Drahoráda z roku 1852. Jako menuet staročeský je v Krolmusově sbírce ještě označena píseň Čtyry koně jdou tamhle za vodou, známá i z jiných pramenů.

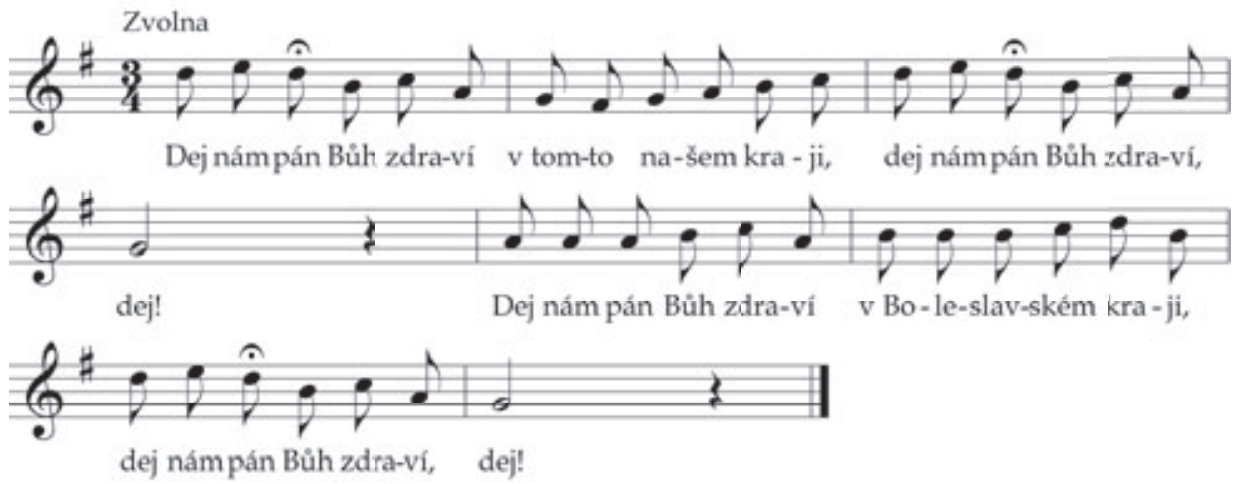

Př́klad 3 V. Krolmus - J. Drahorád, Výbor nápěvů (ed. Janeček 2011-2014), minet starý č. 1, kritická transkripce; záznam před rokem 1852

S menuetem či minetem se lze v Čechách kontinuálně setkat v zápisech od první čtvrtiny 19. do počátku 20. století, přestože z dobových pramenů vyplývá, že byl ve městech $\mathrm{z}$ tanečních pořádků soustavně vytlačován módnějšími tanci, například skotskou (écossaise). ${ }^{8}$ Minet nicméně zůstával součástí výuky městských tanečních mistrů a udržel se - jako protiváha k novým rychlým tancům - i v repertoáru vesnických zábav. Uplatňoval se také v rámci slavnostních příležitostí, zejména ve vazbě na svatební obyčeje. ${ }^{9}$ Od poloviny 19. století se ustálila funkce minetu jako slavnostního zahajovacího tance (Stavělová 1996: 23). Pro jeho mírné tempo a poklidný charakter jej s oblibou tancovala starší generace. ${ }^{10}$

Cenné svědectví o obřadním slavnostním charakteru i pozvolném mizení minetu z českého venkova podává novinář, literát a znalec venkovského prostředí Josef Jaroslav Langer roku 1834: „Co pak se tance samého, totiž staročeského minetu týče, tent zajisté ještě v konečné zapomenutí neklesl; i přesvědčen

8 Podle Jungova „Nářku starého ex-tanečního mistra“ vydaného 1811 v Praze, zatlačovala na začátku 19. století "urozený“ menuet i „pyšnou“ polonézu skotská, docházejíc všude obliby. (Zíbrt 1960: 272).

9 K. V. Adámek (1900: 151) zachytil promluvu družičky: „Dám muzikantům znamení at je minet nebo landryš, kozácká nebo štajryš, budem všichni veselí!"

10 „Naše babičky minet důstojně a rády tančily pro volný rytmus, umírněné tempo, pro eleganci, jistou roztomilost pohybů i pro lahodu poklon, při nichž tanečnice si malebně rozkládaly široké sukně a hedvábné fěrtochy, dvoříce se svým někdejším nápadníkům." (Suchý 1955: 210) 
jsem, že staří takměř všickni, z mladších pak větší díl se na ty ještě nedlouho uplynulé doby pamatuje, když babičky naše, pozvány jsouce na svatbu, své hedbávné zástěry a širokánské sukně ve starodávním minuetu roztahovávaly, jako páv se dvořice a svým někdejším nápadníkům - nyní ovšem již starouškům zbořeniny a drahé pozůstatky své někdejší krásy okazujíce; avšak i upamatování prý milé jest." (Langer 1957: 277-278)

O minetovém tanečním typu a jeho vlastnostech roku 1859 uvažoval Jan Neruda: „Hlavní okrasou všech starších národních tanců byly minety, z nichž jen malá část dosud zachována. Nejen že byly rozmanité $v$ kroku a figurách, ale i jejich texty měly často znamenitou poetickou cenu. Posud známé jsou: Čtyry koně jdou, tamhle za vodou, Dej nám Pánbůh zdraví, v tomto našem kraji ... a jiné. Jejich názvy byly a jsou dosud rozličné; pozdě teprv povstal pro ně kumulativní cizí název minety. "(Neruda 1946: 16-17)

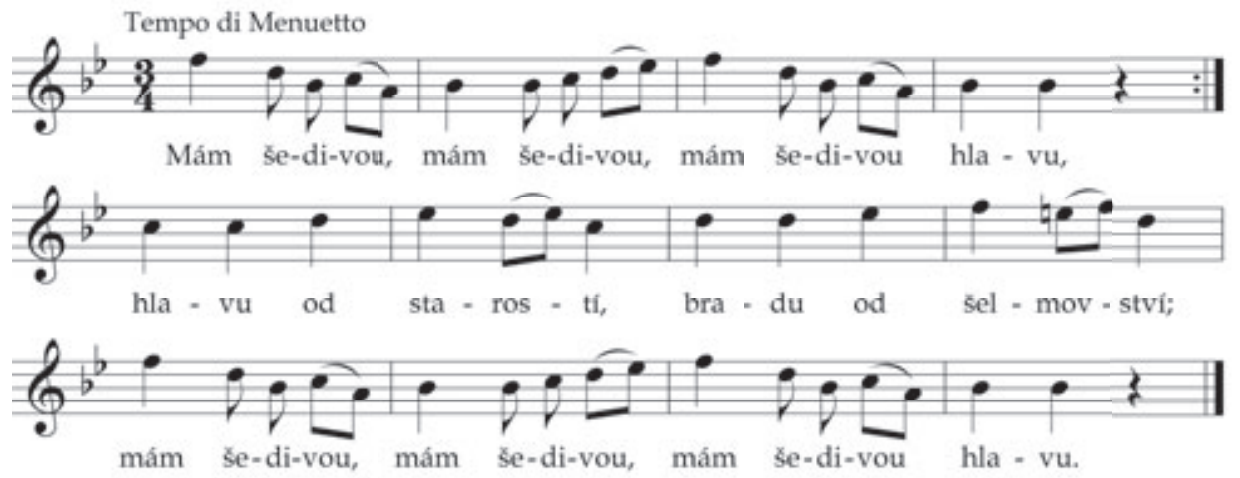

Příklad 4 K. J. Erben (1862), Nápěvy prostonárodních písní českých, menuetto č. 365

Největší soubor více než čtyřiceti notací českých lidových menuetů obsahuje sbírka Karla Jaromíra Erbena Nápěvy prostonárodních písní českých z roku 1862. Zápisy pocházejí z regionů Klatovska (10 záznamů), Hradecka (6), po čtyřech z Chrudimska, Plzeňska, Berounska, Bydžovska a Táborska, tři nápěvy z Prácheňska a po jednom z Bydžovska a Čáslavska. Sporná je u Erbenových záznamů nejednotnost v označování: Někdy užívá explicitní název tance (Menuetto), u většiny tanečních nápěvů tohoto typu je však uveden pouhý předpis tempa (Tempo di Menuetto). V připojeném soupisu tanců sběratel u příslušné položky - navíc jen výběrově - odkazuje na čísla z obou skupin: „Menuet: 97, 365, 449, 491, 700 aj.“(Erben 1862: VI) Pro hudební analýzu bylo využito 41 nápěvů. Desítky „minetových“ písní nejsou v Erbenově sbírce podobně jako v dalších českých pramenech lidových písní - označeny vůbec a nebyly tak do analýzy zahrnuty.

Několik notových záznamů melodií k tanci minet obsahují rukopisné či tištěné sbírky pořizované v souvislosti s přípravou Národopisné výstavy českoslovanské (1895) a v rámci navazujících soukromých i institucionálních výzkumů. Patří 
sem zápis taneční písně z antologie Svatopluka Šebka z Jíkve na Nymbursku"11 (Počkej, Johanes) z roku 1894 a čtyři instrumentální melodie pořízené před rokem 1897 Karlem Václavem Adámkem ve Stanu na Hlinecku a Josefem Zemánkem ve Stříteži, Javorné a Bystřici na Chrudimsku. Několik zpívaných a zvláště cenné série instrumentálních minetů zachytili ještě Čeněk Holas na Písecku a Chrudimsku (1902-1905) a Josef Michal na Hradecku (1904-1913).

Nejmladší notované záznamy minetu v českých sbírkách pocházejí z archivů sběratelů Františka Suchého (Počkej, Johanes) z Nymburska (1912-1915), Josefa Vycpálka (instrum.) z Rychnovska (1919), Karla Weise (Když já přijdu do hospody) z Budějovicka (1932) a Ludmily Danešové, respektive Reginy Husové (Já bych vás, děvčátka, rád vozil ) z Písecka (1940; srov. Soukupová 1980: 156-157). ${ }^{12}$

\section{Tabulka 1 Název tance}

$\begin{array}{lccc}\text { Název tance } & \text { počet zápisů } & \text { Název tance } & \text { počet zápisů } \\ \text { alt böhmischer menuet } & 1 & \text { minet starý } & 1 \\ \text { couravá (minet) } & 1 & \text { minett } & 1 \\ \text { menuet } & 11 & \text { sedlskej minet } & 4 \\ \text { menuetto } & 45 & \text { sousedská, minet } & 1 \\ \text { minet } & 12 & \text { válený minet } & 1 \\ \text { minet (kočárek) } & 1 & \text { válený minet (valčík) } & 1\end{array}$

\section{Hudební analýza}

Výsledky komplexní hudební analýzy přinášejí přehled hudebních kvalit zkoumaných písní a instrumentálních melodií k českému lidovému tanci menuet/ minet a naznačují principy jejich výstavby v rovinách hudební formy, melodiky, metra, rytmiky, tempa a částečně i harmonického plánu. Kritéria a teoretická východiska metody formuloval Lubomír Tyllner (1997). Podstatou objektivního synchronního přístupu k hudebnímu materiálu je odhalení příznačných

11 Jedná se o zápis sběratele Augustina Hajného.

12 Oproti notovým záznamům první taneční popisy minetu pocházejí až z konce 19. století (S. Šebek, K. V. Adámek, J. Zemánek), Ize však předpokládat, že i přes dlouhodobý variační proces byly uchovány jeho příznačné taneční prvky (Stavělová 2007: 561). Býval tancován většinou krokem sousedské nebo valčíku (srov. Stavělová 2008), časté bylo držení za ruce proti sobě, přičemž páry postupovaly bez otáčení dovnitř kruhu a zpět nebo po jiných půdorysných drahách, kdy ustupovala pozadu jen tanečnice a tanečník postupoval za ní. Tanec býval často provázen poklonami a projevy dvoření. Minet měl někdy i volnější formu s jedním typizovaným krokem tančeným do kola bez dalších proměn. Později často splýval s tanečním charakterem lendleru, sousedské či valčíku. Zajímavým dokladem jeho pohybové struktury je rovněž písňový text z rukopisné sbírky ze Sadské: „Jednou v roce / jdem k muzice / o našem Havelským posvícení; / dáme hrát minuet, / v kterém musí umět / dle noty kráčeti / v nadcházení, / při tom jemně vejsknout / a rukama plesknout, / nohama zadupat v zatáčení; / a holka jest ráda, / že má kamaráda, / že v tanci s ní jest / rozveselený.“ (Šebek 1959: 142) 
vlastností v každé jednotce nápěvu i ve zkoumaném repertoáru jako celku. Pro popis těchto vztahů se osvědčily postupy strukturální analýzy (blíže srov. Vejvoda 2013: 80-87).

Komplexní hudební analýza, inspirovaná myšlenkami (zejména lingvistického) strukturalismu, postihuje výstavbové principy písňového nápěvu a následně umožňuje zobecnění v podobě stanovení charakteristických vlastností hudebního (hudebně-tanečního) typu. Každý nápěv je posuzován jako struktura vyššího řádu, která představuje provázaný systém jednotlivých rovin: 1) melodika; 2) rytmika a forma; 3) metrum; 4) tempo; 5) výstavba textu a deklamace. Dosud byla metoda plně využita zejména ve výzkumech nápěvů k tancům do kolečka a lendler (Vejvoda 2002; 2004a; 2004b; 2006; 2008; 2012). Při vyhodnocení hudebních kvalit uceleného sbírkového fondu posloužila při pořádání sběratelského odkazu Oldřicha Blechy (Feiferlíková - Bezděk 2013), Františka Homolky (Vejvoda 2013; 2015) či při výzkumu vlastností písňového repertoáru tzv. guberniální sbírky z roku 1819.

Od roku 2000 je v oddělení etnomuzikologie pražského Etnologického ústavu AV ČR, v. v. i., zpracovávána analyzační databáze českých lidových písní. Dosud bylo podrobně zhodnoceno přibližně 7000 písňových jednotek z rukopisných i tištěných sbírek českých lidových písní od první poloviny 19. století do šedesátých let 20. století.

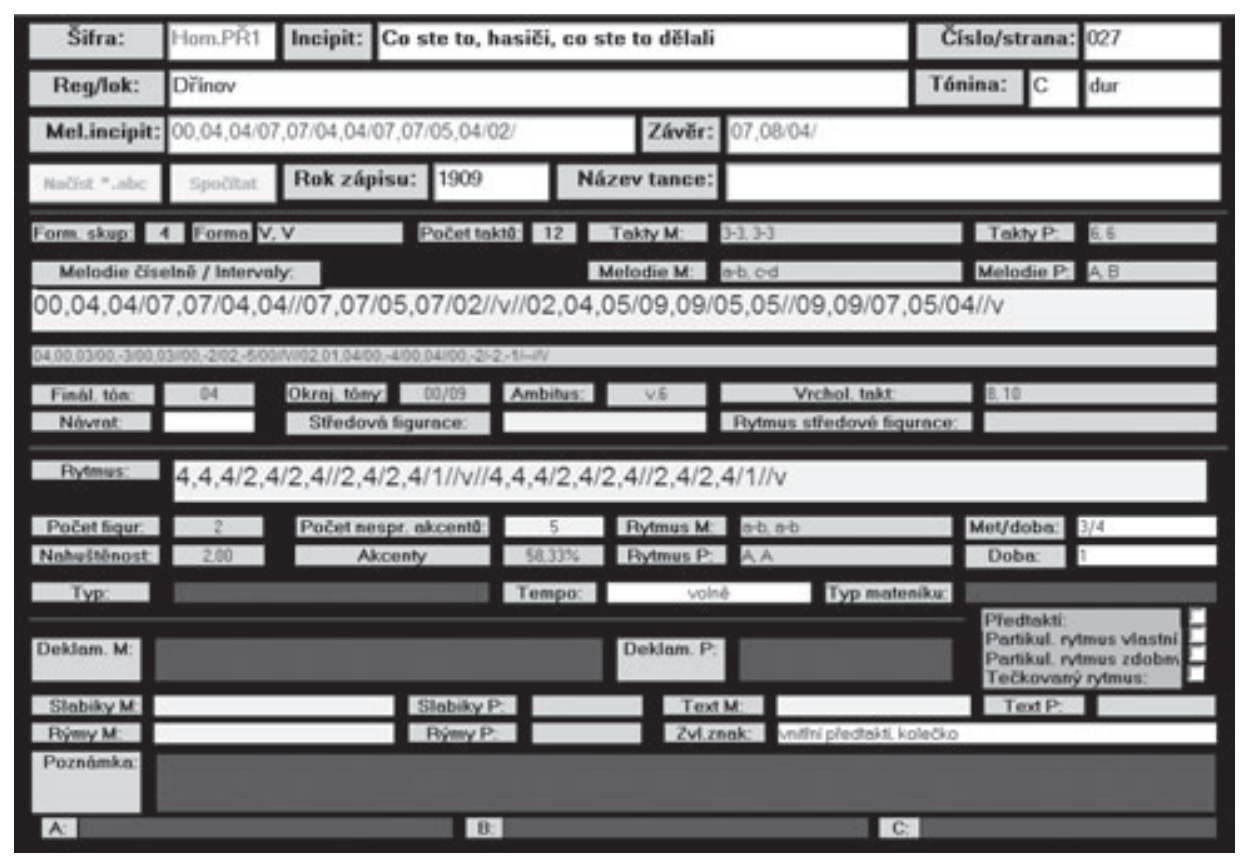

Formulářový list databáze v programu MS Access 


\section{Základní formová charakteristika nápěvů}

Doprovodné písně a instrumentální melodie k českému lidovému tanci menuet jsou nejčastěji osmi- až šestnáctitaktové struktury (v 81 \%), jen zřídka kratší (4-7 taktů) či rozměrnější (18-24 taktů). ${ }^{13}$

Vnitřní formální členění na melodické články je u přesvědčivé většiny (90 \%, tj. 72 nápěvů) výhradně po dvojtaktích a pouhých $8 \%$ ve své vnitřní taktové výstavbě kombinuje dvojtaktí a trojtaktí (příklad 5). Výhradně trojtaktové uspořádání nebylo při analýze zjištěno. ${ }^{14}$

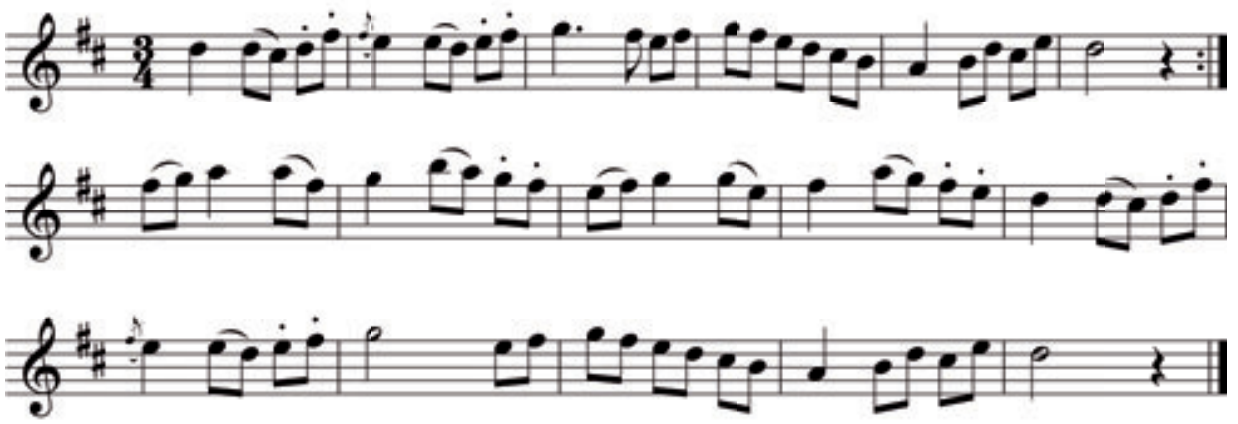

Př́klad 5 Kolovratský rukopis (ed. Markl 1987), menuet č. 205; záznam 1819; trojdílný da capo model $V, V, V$ s vnitřním dělením taktů 3-3, 2-2, 3-3

Relativně vzácné třítaktové melodické články jsou v minetových nápěvech někdy užity také ve funkci malých dílů. Některé vznikly přirozeně v souladu s deklamací, jiné opakováním motivu (příklad 6), jeho augmentací či naopak diminucí. Jde o příznačný jev, který souvisí s napětím mezi jedinečným výrazem konkrétní struktury a obecnou tendencí k symetrii na všech úrovních formové výstavby.

13 Do analýzy nebyly zahrnuty série několika více než třicetitaktových instrumentálních společenských lendlerů (již známých Hartla a Holase), které spíše vypovídají o hudební praxi městských zábav a jejichž rozměry nevyhovují metodě komplexní hudební analýzy folklorních písňových nápěvů.

14 Pro potřeby hudební analýzy lidových písní byl zaveden pojem melodický článek, jenž odpovídá nejmenšímu metrickému skladebnímu prvku, dvojtaktí či trojtaktí. Dále se neužívá pojmu věta, ale tzv. velký díl (V), složený výhradně ze dvou melodických článků, a malý díl (M), samostatný, nepárový melodický článek. 


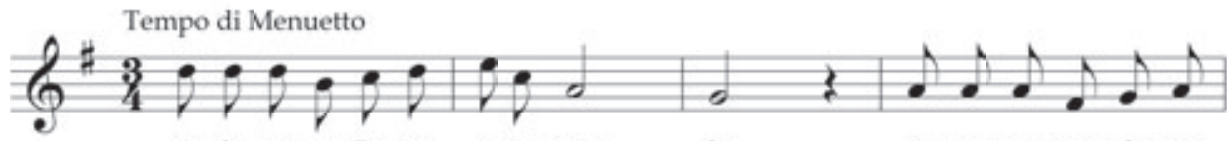

A-le pa-ne Bo-že, tc je švan - da, je to v na-sem do-mě

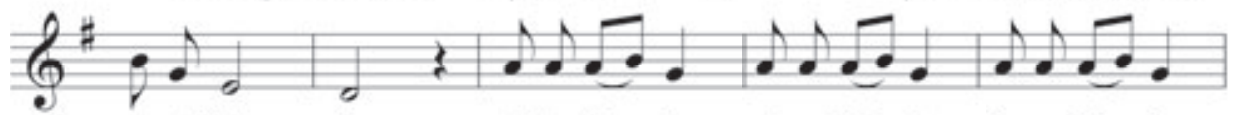

sa-má Man - da: bá-ba Man-da, má-ma Man-da, dce-ra Man-da,

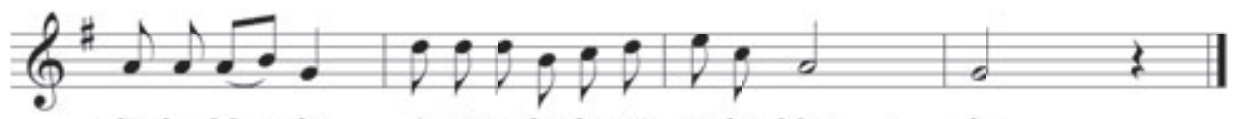

děv-ka Man-da, i ta po-dru-hy-nè ta-ky Man - da.

Př́klad 6 K. J. Erben (1862), Nápěvy prostonárodních písní českých, menuetto č. 22; model $V$, $V, M$ s vnitřním dělením taktů 3-3, 2-2, 3

Tabulka 2 Počet taktů

\begin{tabular}{|c|c|c|}
\hline Počet taktů & celkem nápěvů & $\%$ \\
\hline 16 & 29 & 36 \\
\hline 8 & 24 & 30 \\
\hline 10 & 4 & 34 \\
\hline 12 & 4 & \\
\hline 13 & 3 & \\
\hline 20 & 3 & \\
\hline 22 & 3 & \\
\hline 7 & 2 & \\
\hline 18 & 2 & \\
\hline 19 & 2 & \\
\hline 4 & 1 & \\
\hline 6 & 1 & \\
\hline 14 & 1 & \\
\hline 24 & 1 & \\
\hline
\end{tabular}

Formová skupina (FS) je počet melodických článků (dvojtaktí nebo trojtaktí) v nápěvu. U písní a instrumentálních melodií $\mathrm{k}$ tanci menuet jsou nejčastější formové skupiny: 8 (osm melodických článků v nápěvu - 35 \%), 4 (30\%), $6(11 \%)$ a 5 (6 \%). $18 \%$ má jinou formovou skupinu $(2-3,9-12)$.

Přesvědčivý je počet duplikací konkrétních modelů vnitřního členění nápěvů na melodické články po dvojtaktích a trojtaktích (tabulka 3). Jako ukázku prvního nejčastějšího typu viz příklady 2 a 3. 
Tabulka 3 Modely vnitřního taktového členění melodických článků

Modely členění nápěvů podle taktů celkem nápěvů $\%$

$2-2,2-2,2-2,2-2$ 25 31

$2-2,2-2$ 24 30

$2-2,2-2,2$

4

$2-2,2-2,2-2$ 4 5

3-3, 2-2, 3-3 3 4 jiný 20 25

\section{Velké a malé díly a jejich řazení}

Písmenné vyjádření formy sledovaných menuetových nápěvů v rozsahu velkých a malých dílů ukazuje přesvědčivou řadu duplikací v jejich řazení. Jednoho ze dvou základních symetrických modelů, složených ze čtyř respektive dvou velkých dílů, je užito v 64 \% všech nápěvů (příklady 7, 8).

Malé díly, které vznikají především opakováním a změnami rozměrů motivů a témat (ve složce melické: rozšíření, zúžení, dělení; ve složce rytmické: augmentace a diminuce), byly nalezeny v 21 \% zkoumaných nápěvů (příklad 6).

Tabulka 4 Konkrétní modely řazení velkých a malých dílů

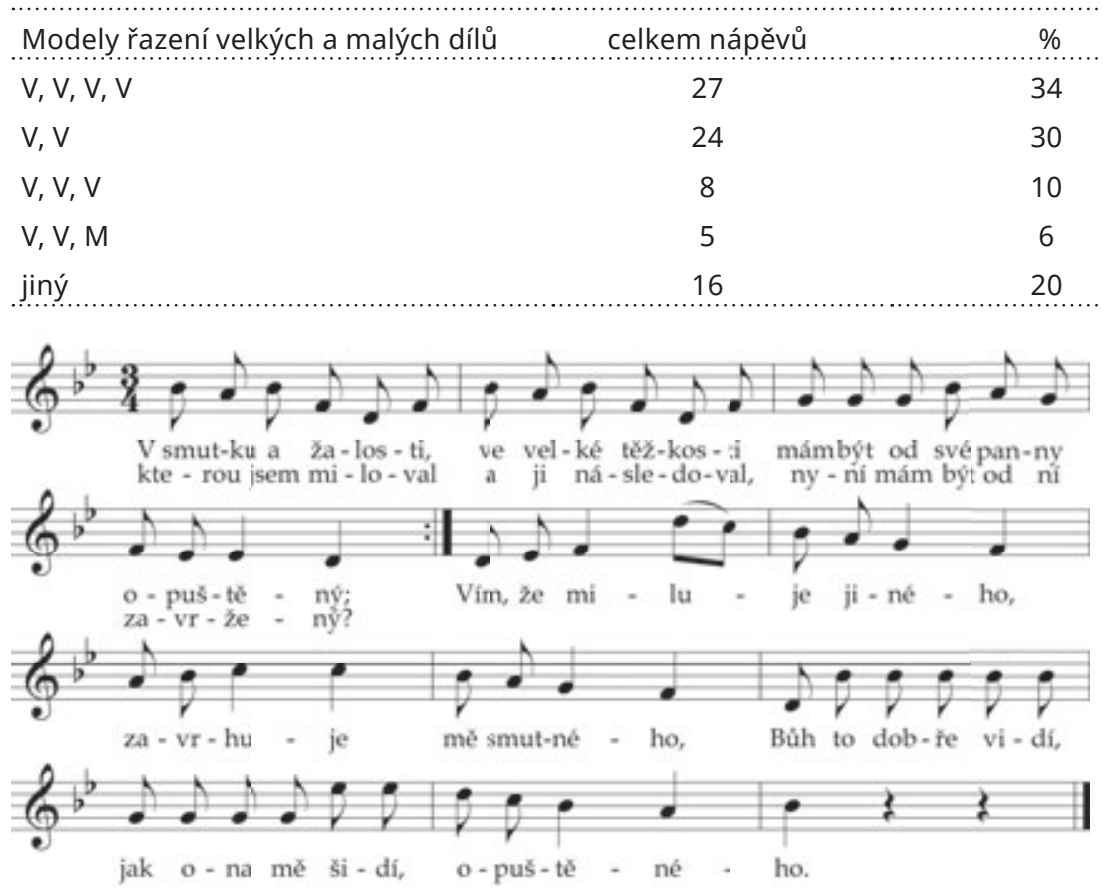

Př́klad 7 Č. Holas (1909), České národní písně a tance IV, minet č. 219; model $V, V, V, V$ s vnitřním dělením taktů 2-2, 2-2, 2-2, 2-2 


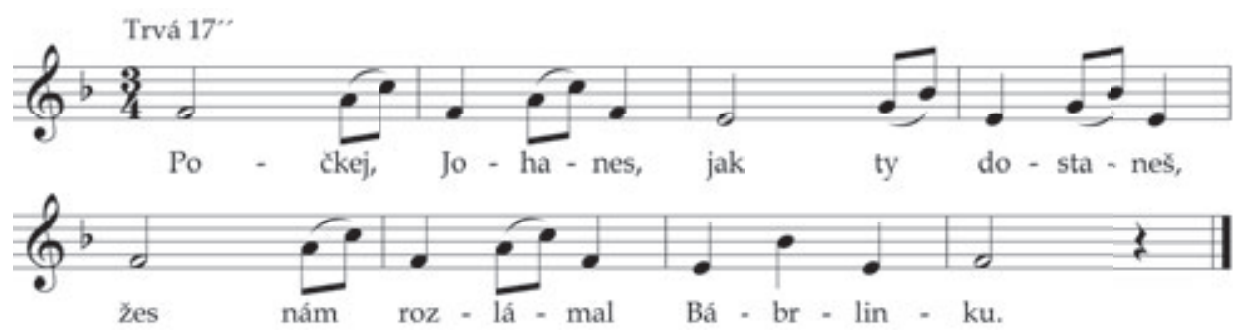

Př́klad 8 F. Suchý (1955), Lidové písně a tance z Polabí..., minet č. 6; model $V$, $V$ s vnitřním dělením taktů 2-2, 2-2

Pro úplnost lze ještě doložit výsledek křížového dotazu na duplikace modelů řazení velkých a malých dílů s vnitřním taktovým uspořádáním podle melodických článků. Jak vyplývá i z předchozích výzkumů, vysoké podíly typů $V, V$ a $V$, $V, V, V$ s vnitřním členěním po dvojtaktích naznačují jisté formové archetypy.

Tabulka 5 Duplikace v řazení velkých a malých dílů s konkrétním vnitřním členěním podle melodických článků

$\begin{array}{lcccc}\text { Řazení velkých a malých dílů } & \text { členění nápěvů podle taktů } & \text { celkem nápěvů } & \% \\ \text { V, V, V, V } & 2-2,2-2,2-2,2-2 & 25 & 31 \\ \text { V, V } & 2-2,2-2 & 24 & 30 \\ \text { V, V, M } & 2-2,2-2,2 & 4 & 5 \\ \text { V, V, V } & 2-2,2-2,2-2 & 4 & 5 \\ \text { V, V, V } & 3-3,2-2,3-3 & 3 & 4 \\ \text { jiné } & & 20 & 25\end{array}$

\section{Hudební forma}

Výsledky analýzy na první pohled naznačují, že charakteristickým znakem menuetových tanečních melodií je lineární (tj. postupně navazující) řazení motivů a témat. Některý z formových vzorců s výhradně lineárním řazením motivů na úrovni velkých a malých dílů využívá 69 \% všech zkoumaných nápěvů. Přesto se však v tomto repertoáru oproti průměrným hodnotám českých tanečních nápěvů (srov. Vejvoda 2004c) mnohem více uplatňuje periodicita, zejména na nižší úrovni melodických článků.

Jak již vyplynulo $\mathrm{z}$ hodnot takzvané formové skupiny, menuetové nápěvy jsou nejčastěji dvou- až pětidílné. Četnější jsou formy $A, B$ (příklad 9), $A, B$, $C, D($ príklad 1$)$ a $A, B, C$.

Trojdílnost s doslovným opakováním (z pohledu klasických hudebních forem v podstatě minitrojdílná forma $A, B, A$ ) se vyskytuje u 4 nápěvů ( 5 $\%$ ), minipětidílná forma $A, B, C, A, B$ nebyla zjištěna. Relativně častá je však 
periodická forma $A, B, C, B$ (15 \% - příklad 10), u níž lze uvažovat o dílu $C$ jako o tzv. středové figuraci. ${ }^{15}$

\section{Tabulka 6 Forma nápěvů}

Hudební forma celkem nápěvů

$\%$

$A, B$ 27

$A, B, C, B$

$A, B, C, D$

10

$A, B, C$ 9

$A, B, A$

4

5

$A, A, B, C$

3

4

$A, B, C, D, E$

3

4

jiná

12

15

Tempo di Menuetto

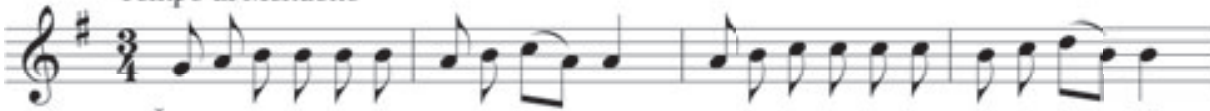

Ško-da je tě,syn-ku, ško-da je tě, pan-tá-ta tě ne-chce mitza ze - tě,

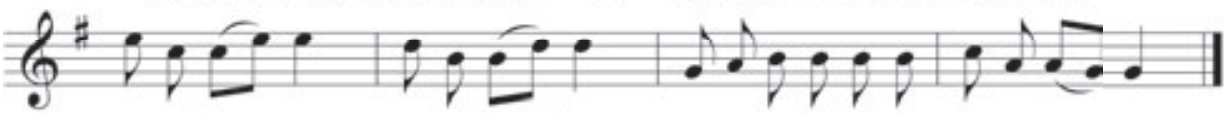

a-ni dce - ra za mi-lé - ho, za-ne-chej cho-ze-ní da-rem-né - ho.

Př́klad 9 K. J. Erben (1862), Nápěvy prostonárodních písní českých, menuetto č. 629; FS: 4; forma $A, B / a-b, c-d$; typ $V, V$; melodické články 2-2, 2-2

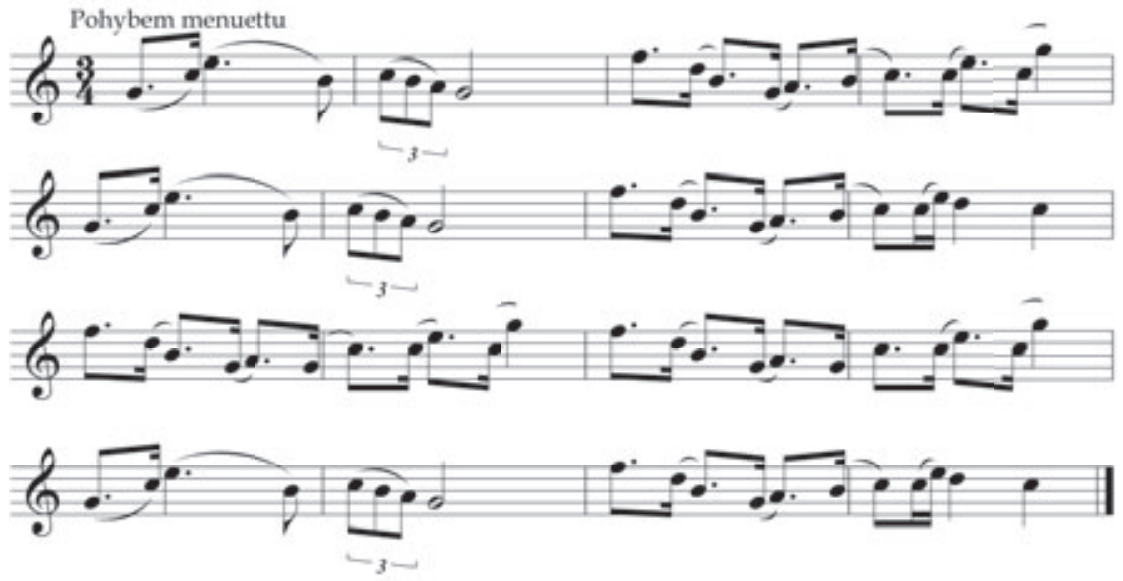

Př́klad 10 J. Zemánek (1912), Tance našich okresů, minet s. 483; FS: 8; forma $A, B, C, B$ / $a-b$, $a-c, d-d, a-c ;$ typ $V, V, V . V$; melodické články 2-2, 2-2, 2-2, 2-2

15 Kontrastní díl mezi expozicí a reprízou rytmických motivů je nazýván středová figurace. Jedná se o tektonický prvek tvořený sledem motivů nižšího významu, který plní úlohu středního dílu. V českých lidových písních je středová figurace nejčastěji tvořena izorytmickou strukturou v rozsahu dvou až čtyř melodických článků. 
Na úrovni melodických článků není řada duplikací hudební formy tak přesvědčivá. Lze jen potvrdit zvláštní postavení typu $A, B$ s vnitřní formální melodickou výstavbou $a-b, c-d$ (20 \%; viz př́íklad 9).

Tabulka 7 Duplikace formy podle velkých a malých dílů s formou podle melodických článků

\begin{tabular}{|c|c|c|c|}
\hline Hudební forma & & celkem nápěvů & $\%$ \\
\hline$A, B$ & $a-b, c-d$ & 16 & 20 \\
\hline$A, B, C, B$ & $a-b, a-c, d-d, a-c$ & 6 & 7,5 \\
\hline$A, B, A$ & $a-b, c-d, a-b$ & 4 & 5 \\
\hline$A, B$ & $a-b, a-c$ & 4 & 5 \\
\hline$A, B, C, D$ & $a-b, a-c, d-e, d-f$ & 3 & 4 \\
\hline$A, B, C, B$ & $a-b, a-c, d-e, a-c$ & 3 & 4 \\
\hline$A, B$ & $a-b, c-a$ & 3 & 4 \\
\hline jiná & & 26 & 32 \\
\hline
\end{tabular}

Shrnutí: Menuety z českých sbírek jsou z hlediska základní formové charakteristiky až na výjimky kratší, s vnitřním dělením téměř výhradně po dvojtaktích. Jako charakteristická se jeví tendence k symetrii formy, která je z deklamačních a textových důvodů výjimečně porušována (užití malých dílů ve formové výstavbě u pětiny nápěvů). Na nižší úrovni melodických článků se častěji uplatňuje periodicita, na úrovni velkých a malých dílů spíše lineární řazení motivů a témat. Nejčastější způsob řazení velkých a malých dílů představují dvou- až čtyřdílné modely složené ze samých velkých dílů $(V, V-V, V, V, V)$. Charakteristická forma zkoumaných nápěvů je $A, B$ a $A, B$, $C, B$, resp. $A, B, C, D$.

\section{Tóniny a tonalita}

U všech menuetových melodií byla zkoumána tonalita. Výsledkem je, že všechny zápisy jsou výhradně durové. U dvou nápěvů (příklad 11) byla zaznamenána modulace do subdominantní tóniny.

Konkrétní tóniny (za předpokladu, že sběratel zapisuje písně v poloze, v níž byly v terénu provozovány) jsou určeny jednak hlasovým rozsahem a dispozicí zpěváka, jednak (u zápisů tanečních melodií př̀i taneční zábavě) jsou závislé na možnostech a ladění doprovodných hudebních nástrojů. Vzhledem $\mathrm{k}$ různorodé povaze a provenienci analyzovaného materiálu nelze o takové relaci výsledných záznamů ke konkrétní tónině obecně rozhodnout. 
Tabulka 8 Konkrétní tóniny zápisů

Tónina

G dur

F dur

C dur

D dur

B dur

A dur

As dur

Es dur

G - C dur celkem nápěvů $\%$

22

18

11

10

9

4

2

2

2
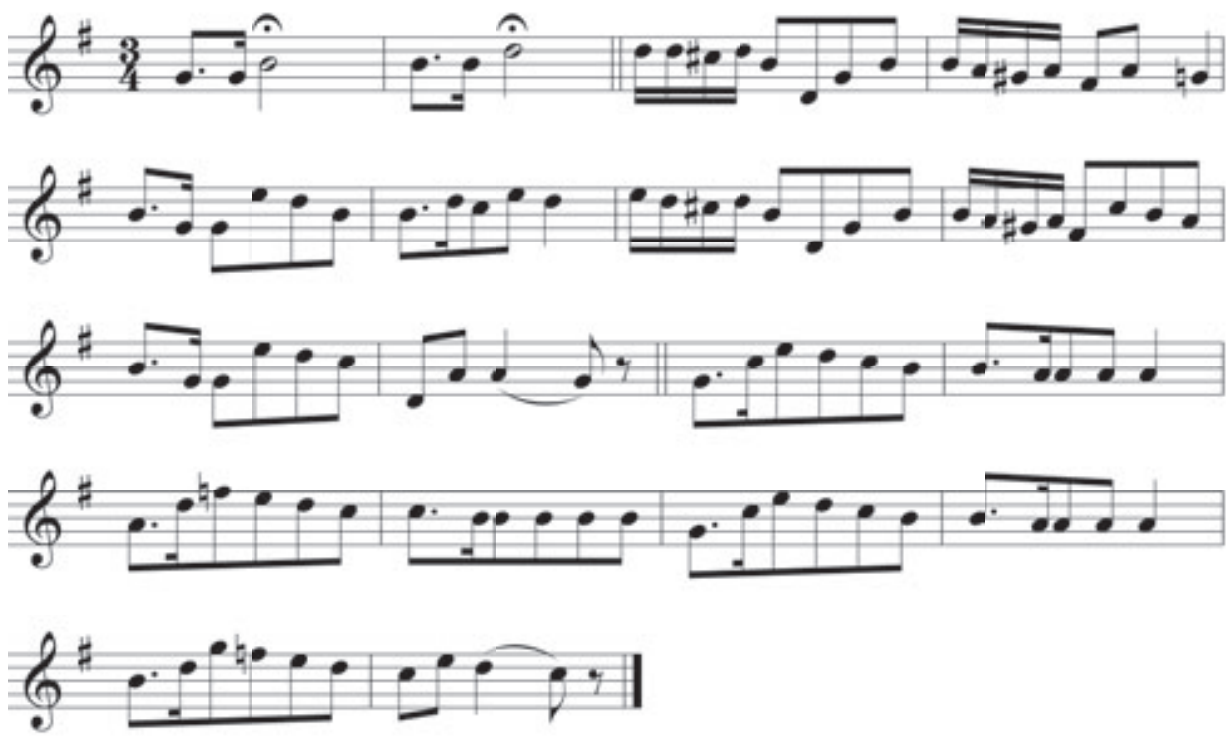

Př́klad 11 J. Vycpálek (1921), České tance, minet s. 71; FS: 9; forma $A, B, C, D, E / a, b-c, d-e, f-g$, $f$-h; typ $M, V, V, V . V$; melodické články 2, 2-2, 2-2, 2-2, 2-2

Shrnutí: Nápěvy českých lidových menuetů vykazují v rovině tonální analýzy ustálené dur-mollové cítění. Jsou výhradně v tónině tvrdé, z konkrétních tónin nejčastěji v $G$ dur a F dur.

\section{Melodika}

Tónový rozsah zkoumaných nápěvů v průměru odpovídá zjištěným hodnotám ze sbírek českých lidových písní z 19. století. Většinou nepřesahuje velkou nónu (84 \%). Větší ambity souvisejí s převážně instrumentální povahou daného materiálu. 
Nejmenší rozsahy čisté kvinty a velké a malé sexty odpovídají hudebnímu typu žertovných popěvků odkazujících spíše k mazurce (příklady 12,13) či k tanci do kolečka. Největší - z hlediska rozsahu lidského hlasu ale nijak výjimečný - rozsah čisté undecimy (kvarta přes oktávu) byl zjištěn u 10 nápěvů.

\section{Tabulka 9 Ambitus}

Ambitus

č. 8

m. 7

v. 9

m. 9

č. 11

v. 6

m. 6

v. 10

č. 5

m. 10

v. 7 celkem nápěvů $\%$

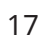

13

12

11

10

6

5

2

1

1

1
21

16

15

14

13

8

6

7

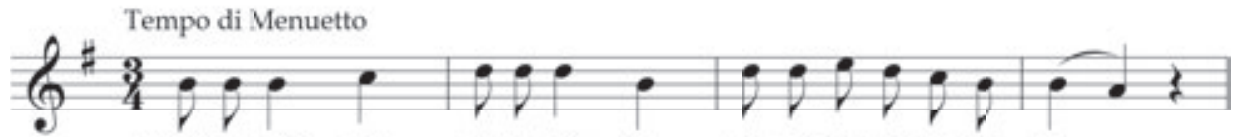

Kdyžsem šel skrz du-bo-vý les, pre-pad-la mě dří-ro - ta,

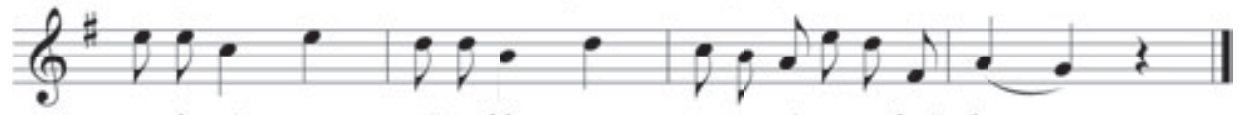

a do rá - na mné za hla - vou roz-ma-rý-na vy-květ-la.

Příklad 12 K. J. Erben (1862), Nápěvy prostonárodních písní českých, menuetto č. 297; ambitus $m$. 7, okrajové tóny $-1 / 09$

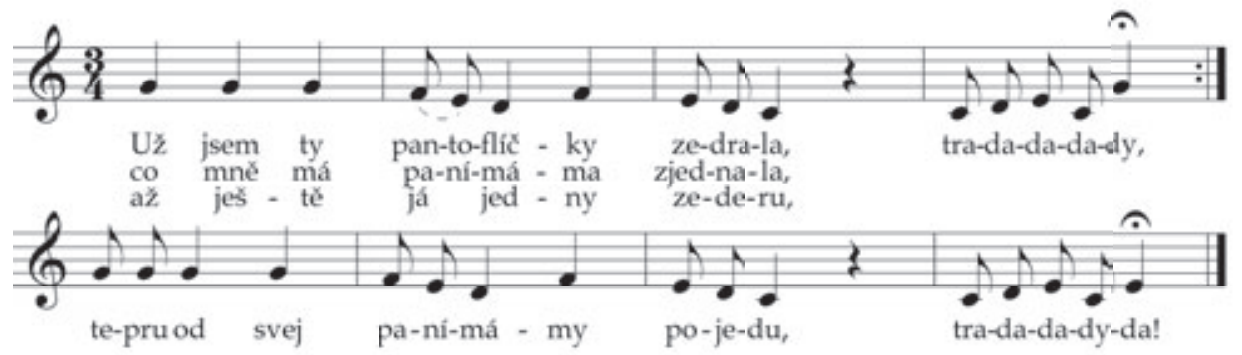

Příklad 13 Č. Holas (1910), České národní písně a tance V, válený minet č. 183; ambitus č. 5, okrajové tóny 00/07 
Tónové rozsahy jsou závislé na okrajových tónech (tj. na nejnižším a nejvyšším tónu každého nápěvu). Z výsledků analýzy vyplývá, že při tónovém rozsahu č. 8 je melodie nejčastěji položena tak, že okrajové tóny tvoří první a osmý stupeň (11 \% všech nápěvů) nebo spodní čtvrtý a svrchní pátý stupeň (10 \%). U ambitu $m .7$ jsou to spodní druhý a svrchní šestý stupeň (12\%) diatonické řady (př́́klad 13). U v. 9 jsou to nejčastěji spodní čtvrtý a svrchní šestý stupeň (12 \%) a m. 9 spodní druhý a svrchní osmý stupeň diatonické řady (10 \%).

Tabulka 10 Ambitus a okrajové tóny (křížový dotaz)

\begin{tabular}{|c|c|c|c|}
\hline Ambitus & okrajové tóny & celkem nápěvů & $\%$ \\
\hline m. 7 & $-1 / 09$ & 10 & 12 \\
\hline v. 9 & $-5 / 09$ & 10 & 12 \\
\hline č. 8 & $00 / 12$ & 9 & 11 \\
\hline m. 9 & $-1 / 12$ & 8 & 10 \\
\hline č. 8 & $-5 / 07$ & 8 & 10 \\
\hline č. 14 & $-5 / 12$ & 7 & 9 \\
\hline v. 6 & $00 / 09$ & 6 & 8 \\
\hline zv. 5 & $-1 / 07$ & 5 & 7 \\
\hline jiné & & 17 & 21 \\
\hline
\end{tabular}

Nápěvy písní a instrumentálních melodií k českým lidovým menuetům v melodice využívají celého spektra intervalových vzdáleností. Zkoumány byly všechny intervaly dvou sousedních tónů melodie, bez ohledu na to, jsou-li odděleny hranicí taktů, či melodických článků. Většina nápěvů používá postupy sekundové, terciové a kvartové, téměř polovina nápěvů (zejména na hranicích melodických článků) navíc kvintových či sextových melodických skoků. Zanedbatelný také není podíl 16 \% nápěvů s oktávovými skoky. Největší interval, který byl zjištěn mezi dvěma sousedními tóny ve dvou zkoumaných nápěvech, byla velká nóna (sekunda přes oktávu). Kvarty, kvinty a oktávy jsou výhradně čisté, septimy a sexty malé a velké.

Tabulka 11 Melodické postupy a skoky

\begin{tabular}{|c|c|c|}
\hline intervaly & celkem nápěvů & $\%$ \\
\hline sekundy a tercie & 7 & 9 \\
\hline navíc kvarty & 62 & 78 \\
\hline navíc kvinty & 36 & 45 \\
\hline navíc sexty & 32 & 40 \\
\hline navíc septimy & 9 & 11 \\
\hline navíc oktávy & 13 & 16 \\
\hline větší mel. skoky & 3 & 4 \\
\hline
\end{tabular}


Výsledky výzkumu počátečních tónů úvodního motivu a finálních tónů celého nápěvu odpovídají tonální a harmonické vyhraněnosti analyzovaných nápěvů. Tonálně ukotvená melodie nejčastěji začíná a končí na tónice či na jiném tónu tónického kvintakordu. Jednoznačně převažuje tzv. úplný závěr.

Tabulka 12 Počáteční tón (stupeň diatonické řady)

$\begin{array}{lll}\text { Počáteční tón } & \text { celkem nápěvů } & \% \\ 00 \text { (1. stupeň) } & 34 & 43 \\ 07 \text { (5. stupeň) } & 13 & 16 \\ -5 \text { (spodní 4. stupeň) } & 11 & 14 \\ 12 \text { (8. stupeň) } & 11 & 14 \\ 04 \text { (3. stupeň) } & 9 & 11 \\ 09 \text { (6. stupeň) } & 1 & 2 \\ 05 \text { (4. stupeň) } & 1 & \end{array}$

Tabulka 13 Finální tón (stupeň diatonické řady)

\begin{tabular}{|c|c|c|}
\hline Finální tón & celkem nápěvů & $\%$ \\
\hline 00 (1. stupeň) & 67 & 84 \\
\hline 04 (3. stupeň) & 7 & 6 \\
\hline 12 (8. stupeň) & 5 & \\
\hline -5 (spodní 4. stupeň) & 1 & \\
\hline
\end{tabular}

Spíše výjimečné jsou počáteční tóny na šestém a čtvrtém stupni. Jejich původ je ve stř́́davých a průchodných tónech, nebo souvisí s harmonickým plánem celého nápěvu (příklad 14).

Čtvrtý a spodní čtvrtý stupeň na pozici finálního tónu svojí otevřeností odrážejí praxi dlouhých sérií tanečních melodií téhož (zde menuetového) typu.

Tabulka 14 Chromatika

$\begin{array}{llcc}\text { pramen } & \text { incipit } & \text { nedoškálný tón } & \text { povaha chromatiky } \\ \text { Vycp. } 17 & \text { (instrum.) } & 01,06 & \text { zdobná } \\ \text { EN 258 } & \text { Kdyby moje milá samé pentle byla } & 01 & \text { zdobná } \\ \text { Kunz 27 } & \text { Však já mou Marjánku znám } & 01 & \text { zdobná } \\ \text { EN } 365 & \text { Mám šedivou hlavu } & 06 & \text { zdobná } \\ \text { Kunz 28 } & \text { Nic nedbám, jen když mám } & 06 & \text { harmonická } \\ \text { EN 739 } & \text { Vstávej, vstávej zhůru, myslivečku } & 06 & \text { zdobná } \\ \text { EN 758 } & \text { Vždycky jen se ptala, kde armáda stála } & 06 & \text { zdobná }\end{array}$


Nápěvy zkoumaných písní a instrumentálních melodií jsou většinou pouze diatonické. Chromatika, omezená výhradně na užití zm. 5 (zv. 4), m. 2 (zv. 1) a zv. 6 (zm. 7), má svůj původ v ornamentice nástrojové hry. To určuje její povahu a zdobnou, výjimečně i harmonickou funkci.

$Z m .5$ je užito v 5 nápěvech z celkového počtu 80, často i více než jednou, chromatiku obecně najdeme u 7 záznamů ( $9 \%$ ). Její zřetelně ornamentální povahu lze určit v šesti z nich (př́íklad 4). Jedenkrát je jí užito v jiné funkci: jako harmonický prostředek mimotonální dominanty (či tóninového vybočení) na exponovaném místě středové figurace (příklad 14).

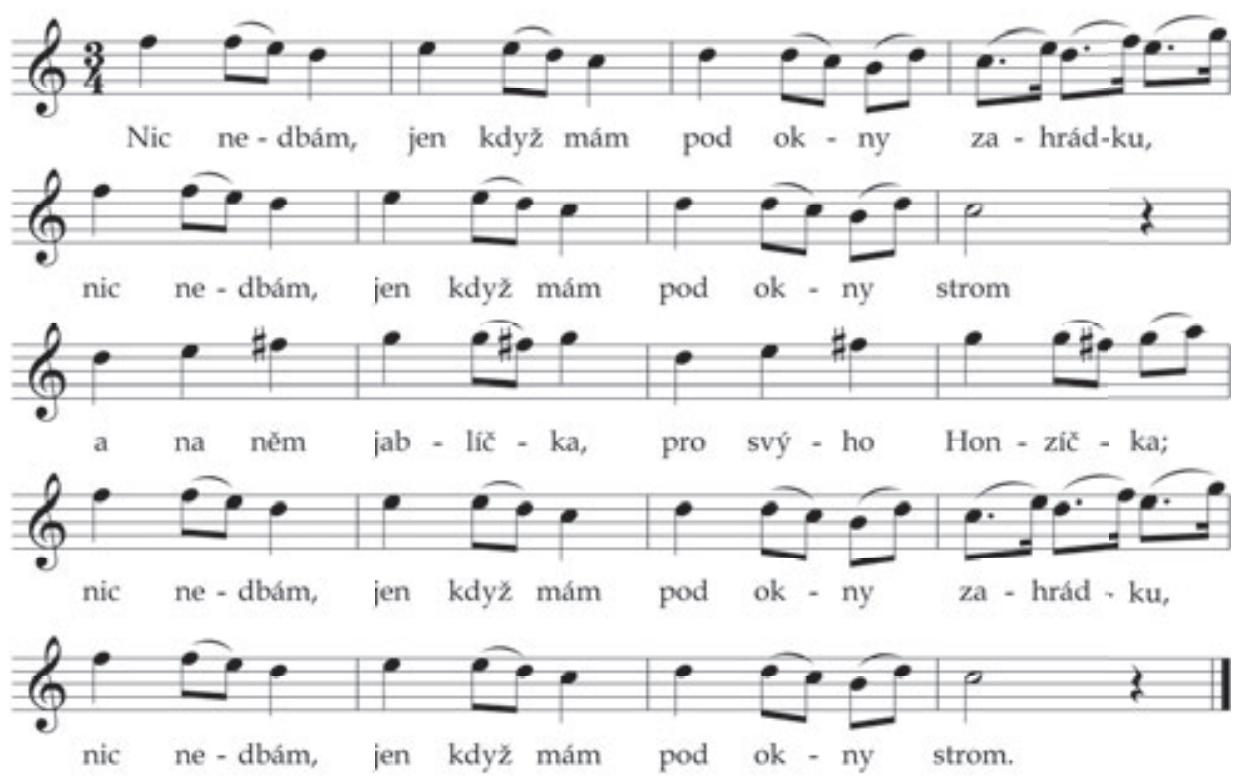

Př́klad 14 T. A. Kunz (ed. Tyllner 1995), České národní zpěvy a tance, sedlskej minet č. 28 (1819); FS: 10; forma $A, B, C, A, B / a-b, a-c, d-d, a-b, a-c$; typ $V, V, V, V . V$; melodické články 2-2, 2-2, 2-2, 2-2, 2-2; nedoškálný tón 06 (zv. 4) harmonické povahy

Shrnutí: Základní charakteristickou vlastností menuetových nápěvů písní v rovině melodické analýzy je střední tónový rozsah (nejčastěji do v. 9). Svým původem instrumentální melodika nepostrádá výraznější klenutí. Intervalové vzdálenosti mezi tóny jsou nejčastěji sekundové až kvartové, poměrně časté však jsou i větší melodické skoky. Počáteční a finální tóny nápěvů většinou odpovídají tonální a harmonické vyhraněnosti českého lidového zpěvu. Zřídka užitá chromatika má zdobnou a výjimečně i harmonickou povahu. 


\section{Metrika}

Při komplexní hudební analýze je vždy zásadní otázkou revize metra a následný kritický metrorytmický zápis. Chybná notace totiž zkresluje formální, rytmickou i melodickou výstavbu. Ve zcela jiném světle se pak jeví i vztah nápěvu k textu a deklamaci. ${ }^{16}$

V písních a instrumentálních melodiích $\mathrm{k}$ tanci menuet z českých sbírek 19. a 20. století lze konstatovat jako výhradně třídobé metrum. Jediný zápis (příklad 15a) ve své metrické výstavbě kombinuje trojdobost s dvojdobostí. Editor sbírky Josef Michal zápis interpretuje jako tanec s proměnlivým metrem (mateník). Na základě četných variant však lze u tohoto nápěvu opět konstatovat latentní pravidelnou trojdobost (příklad 15b), porušenou zřejmě fixovanou rubatovou interpretací, ačkoliv záměrnou hru s hudebně-tanečním metrem nelze také zcela vyloučit.

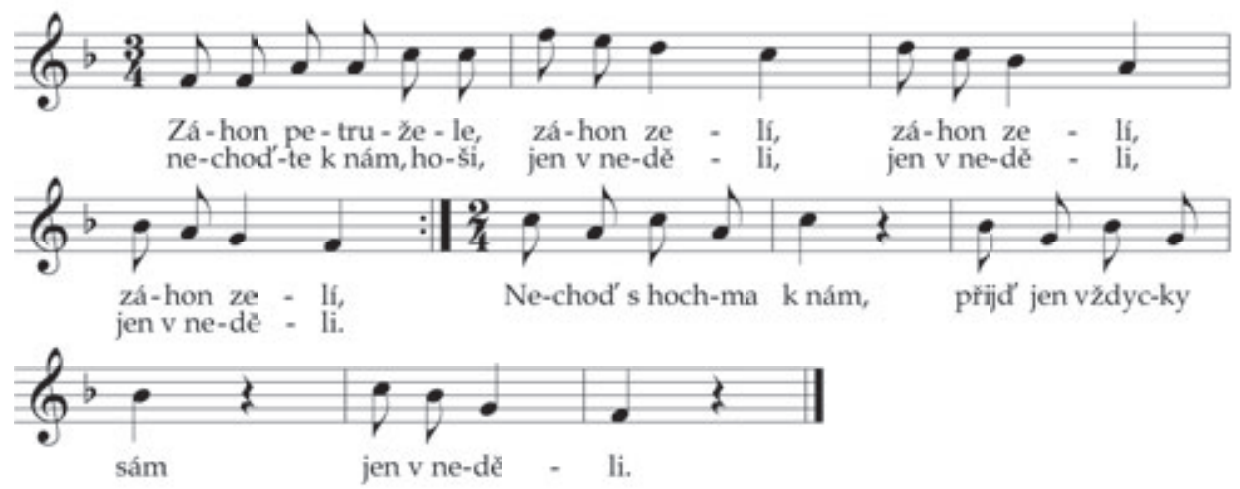

Př́klad 15a J. Michal (1913), Písně a tance z Hradecka, couravá (minet) č. 6

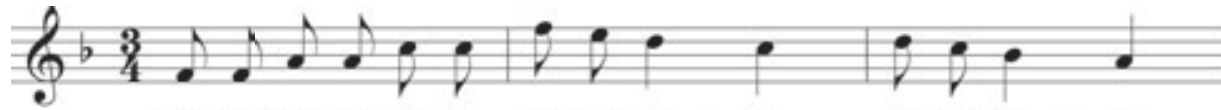

Zá-hon pe-tru-že-le, zá-hon ze - lí, zá-hon ze - li, ne-chod'-te k nám, ho-ši, jen v ne-dé - li, jen v ne-dè - li,

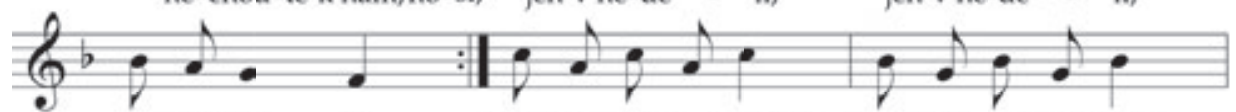

zá-hon ze - li, Ne-chod's hoch-ma k nám, př́ijd' jen vždyc-ky sám

jen v ne-dé - li.

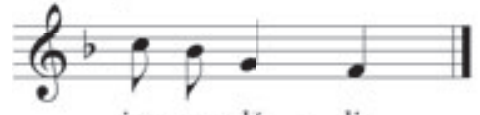

jen v ne-dé - li.

Př́klad 15b Hypotetický tvar beze změny metra

16 V tomto smyslu bylo nutné kriticky transkribovat chybný Drahorádův zápis písně z Krolmusovy sbírky (př́klad 3). V originále je notována s předtaktími a rozepsanými fermatami, které zcela zamlžují metrum, rytmus i symetrickou hudební formu. 
Konkrétní označení taktu se obecně liší podle individuálního způsobu zápisu sběratelů, je však ovlivněno i dobovou praxí. Důležitou roli hraje rozdílně chápané tempo tanečních písní ve $3 / 4$ respektive $3 / 2$ či 3/8 taktu. Jednoznačně převažuje předpis taktu $3 / 4$.

Tabulka 15 Konkrétní označení taktu

\begin{tabular}{|c|c|c|}
\hline Takt & celkem nápěvů & $\%$ \\
\hline $3 / 4$ & 77 & 96 \\
\hline $3 / 2$ & 1 & 4 \\
\hline $3 / 4,3 / 8,3 / 4$ & 1 & \\
\hline $3 / 4,2 / 4$ & 1 & \\
\hline
\end{tabular}

Užití tzv. předtaktí nebylo u českého lidového menuetu - poněkud překvapivě zjištěno, s výjimkou jediné instrumentální melodie (válený minet, Hol. V 280).

Shrnutí: Nápěvy k českému lidovému menuetu jsou výhradně třídobého metra, konkrétní označení taktů je $3 / 4$. V souvislosti s metrem nebyly zjištěny závažné omyly v notaci, které by přinesly nesoulad mezi taktem, deklamací a metrem.

\section{Rytmická analýza}

Rytmus písní a instrumentálních melodií k českým menuetům je různorodý, proměnlivý a přirozeně souvisí s melodikou, textem a deklamací. Spektrum rytmických hodnot sahá od šestnáctin, přes hodnoty osminové, čtvrtové a půlové k hodnotě cele vyplňující takt (ve $3 / 4$ taktu půlová nota s tečkou). ${ }^{17}$

Největší část zkoumaných zápisů (39 \%) je tvořena třemi rytmickými figurami (př́íklad 16). Obvyklé jsou také kombinace dvou, čtyř a pěti figur. Čtyři nápěvy vystačí s jedinou rytmickou figurou, nejvyšší počet je šest figur.

Tabulka 16 Počet rytmických figur v rozsahu melodických článků

\begin{tabular}{|c|c|c|}
\hline Počet figur & celkem nápěvů & $\%$ \\
\hline 3 & 31 & 39 \\
\hline 4 & 17 & 21 \\
\hline 2 & 14 & 18 \\
\hline 5 & 10 & 12 \\
\hline 1 & 4 & 5 \\
\hline 6 & 4 & 5 \\
\hline
\end{tabular}

17 Rytmická analýza v tomto pojetí nepracuje s pauzami, hodnoty jsou vždy přizpůsobeny základnímu předpokladu cele vyplněného taktu, například dvě noty čtvrtové a čtvrtová pauza jsou v 3/4 taktu chápány jako synkopická figura 4, 2 (čtvrtová a půlová). 
Tabulka 17 Řazení a opakování figur v rozsahu melodických článků

Rytmické figury

$a-a, a-b$

$a-b, a-c, b-b, a-c$

$a-b, c-c, a-b$

a-a, a-a

$a-a, b-a$

$a-b, a-b$

$a-b, a-b, c-c, a-b$

$a-b, a-c, d-d, a-c$

$a-b, a-c, d-e, a-c$

$a-b, c-d$

jiná

\section{celkem nápěvů}

$\%$

$\begin{array}{lc}4 & 5 \\ 4 & 5 \\ 4 & 5 \\ 3 & 4 \\ 3 & 4 \\ 3 & 4 \\ 3 & 4 \\ 3 & 4 \\ 3 & 4 \\ 3 & 4 \\ 47 & 57\end{array}$

Tabulka 18 Řazení a opakování rytmických figur v rozsahu velkých a malých dílů Rytmické figury celkem nápěvů $\%$

A, B 21 26

$A, B, C, B$

13 16

$A, B, C$

9

11

A, A

6

8

$A, A, B, C$

6

8

$A, A, B, A$

4

5

$A, B, A$

4

5

jiná

17

Přehled duplikací řazení rytmických figur v rozsahu velkých a malých dílů ukazuje těsné sepětí rytmické struktury nápěvu s hudební formou. Ani repertoár „velkých“ rytmických figur není příliš rozsáhlý, nejčastěji dvě až tři v rozsahu velkých dílů. Nejméně je (pro menuet netypicky) v nápěvu užita jedna figura (příklad 17), nejvýše pět figur.

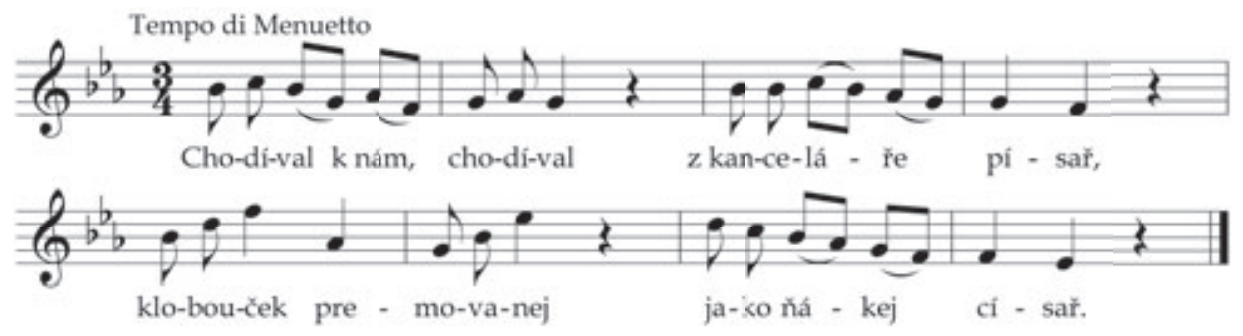

Příklad 16 K. J. Erben (1862), Nápěvy prostonárodních písní českých, menuetto č. 139; počet rytmických figur: 3 ; řazení rytmických figur: $a-b, c-b / A, B$ 


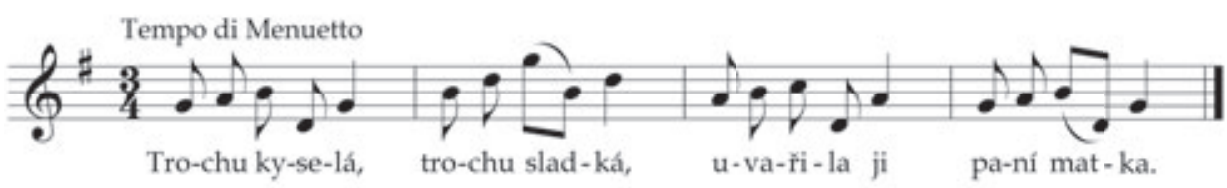

Příklad 17 K. J. Erben (1862), Nápěvy prostonárodních písní českých, menuetto č. 670; počet rytmických figur: 1; řazení rytmických figur: $a-a / A$

Ve zkoumaných třídobých nápěvech byly u 62 z nich (78 \%) - velmi příznačně - nalezeny tzv. partikulární rytmy. Jedná se o rytmicko-deklamační modely, ve kterých (v rozměrech 3/4 taktu) odpovídá slabika textu osminové hodnotě. ${ }^{18}$ Partikulární rytmus vzniká někdy jako zdobný instrumentalismus - zúžením dvojtaktového motivu do jednoho taktu nebo změnou hudebního metra nápěvu s použitím původního textu.

Tečkovaný rytmus je užit v 21 menuetových zápisech (26 \%), spíše výjimečné je v rytmické výstavbě užití triol (příklady 1,9 ).

Shrnutí: Spektrum rytmických hodnot (počítáno v rozměrech 3/4 taktu) sahá od šestnáctin, přes hodnoty osminové, čtvrtové a půlové k hodnotě cele vyplňující takt. Typické jsou kombinace dvou až tří rytmických figur na úrovni velkých a malých dílů. Téměř tři čtvrtiny nápěvů využívají ve své formální výstavbě partikulárních rytmických modelů, třetinový podíl mají melodie s tečkovaným rytmem.

\section{Tempo}

Označení pohybu menuetových tanečních nápěvů z českých sbírek 19. a 20. století - pokud je v záznamech předepsáno - je realizováno prostřednictvím českého i italského názvosloví a jejich rozpětí je od andante resp. zvolna až po allegro. Výjimečně je tempo v nejnovějších edicích předepsáno číselnou hodnotou Mälzelova metronomu či trváním v sekundách. U více než třetiny záznamů označení tempa chybí. Ne příliš vypovídající pro aktuální výzkum jsou rovněž časté předpisy tempo di menuetto či pohybem menuetu, které ze své povahy rovněž nemohou přinést objektivní informaci. Obecně však lze - s využitím zpráv pamětníků - u lidového menuetu konstatovat spíše mírnější tempo. 
Tabulka 19 Tempová označení

Tempo celkem nápěvů

tempo di menuetto 38

neuvedeno 28

andante / andante di menuetto

pohybem minetu/menuettu

3

zvolna / zvolna, laškovně

3

allegro

1

allegro moderato

\section{Hudební typ českého lidového menuetu}

Přikročíme-li k celkovému shrnutí, představují nápěvy menuetů z českých sbírek lidových písní z hlediska formové charakteristiky většinou kratší útvary, s vnitřním dělením téměř výhradně po dvojtaktích. Vlivem textu je výjimečně porušována symetrie formy, mimo jiné užitím malých dílů, nepárových melodických článků. Na elementární formové úrovni se částečně uplatňuje periodicita, na úrovni velkých a malých dílů spíše lineární řazení motivů a témat. V rovině tonální analýzy vykazují nápěvy ustálené dur-mollové cítění, zcela převažuje tvrdá tónina a diatonika, v rovině melodické analýzy mají nápěvy střední tónový rozsah a výraznější klenbu melodie, nápěvný typ je spíše obecně instrumentální. Intervalové vzdálenosti mezi tóny jsou nejčastěji sekundové až kvartové, výjimkou však nejsou ani větší melodické skoky. Počáteční a finální tóny odpovídají tonální a harmonické vyhraněnosti českého lidového zpěvu. Metrum je třídobé, jeho notace v zásadě správná, spektrum rytmických hodnot sahá od šestnáctinových not až k hodnotám cele vyplňujícím 3/4 takt. Typické jsou kombinace dvou až tři rytmických figur na úrovni velkých a malých dílů. Pohyb je mírný, konkrétní předpisy tempa jsou realizovány prostřednictvím italského i českého názvosloví; u třetiny záznamů označení tempa chybí.

Podobně jako u ostatních tanečních nápěvů (srov. Vejvoda 2008; 2012) lze i u českých lidových menuetů konstatovat vzájemné ovlivňování dalšími hudebně-tanečními typy: 1) lendlerem, zejména jeho příznačnou akordickou melodikou a proměnlivou rytmikou (příklad 8); 2) mazurkou s příznačnou rytmickou figurou 8,8,4,4 a symetrickou hudební formou vystavěnou po dvojtaktových melodických článcích (příklad 13); 3) polonézou s charakteristickým tečkovaným rytmem a šestnáctinovým pohybem jako nejvýraznějšími znaky (př́klad 11).

Z hudební analýzy vyplývá, že z celku 80 zevrubně prozkoumaných menuetových melodií 38 položek (48 \%) odpovídá výše popsaným charakteristickým vlastnostem „českého“ menuetu. Šestnáct nápěvů (20 \%) se svými hudebními 
kvalitami blíží mazurce, deset (13\%) vykazuje znaky doprovodných písní k tanci do kolečka a sedm (9 \%) připomíná lendler. Pět melodií (6 \%) vykazuje znaky hned několika třídobých hudebních typů.

Komentované výsledky komplexní hudební analýzy doprovodných písní a instrumentálních melodií v českých sbírkách označených jako minet/menuet dokládají, jak se všechny výše jmenované hudebně-taneční typy vzájemně ovlivňovaly, prostupovaly a překrývaly. Právě menuet však lze rozhodně označit za nepřehlédnutelný článek vývoje české hudebnosti a tanečnosti 18. a 19. století. Budoucí muzikologický a zvláště choreologický výzkum jistě ještě docení jeho významnou, nezastupitelnou roli v české hudební a taneční kultuře.

\section{Říjen 2016}

\section{Prameny a literatura}

Adámek, Karel Václav. 1900. Lid na Hlinecku. Praha: Archaeologická kommisse při České akademii císaře Františka Josefa pro vědy, slovesnost a umění.

Bartoš, František - Janáček, Leoš. 1901. Národní písně moravské v nově nasbírané. Praha: České akademie císaře Františka Josefa pro vědy, slovesnost a umění.

Erben, Karel Jaromír. 1862. Nápěvy prostonárodních písní českých. Praha: nákladem vydavatelovým.

Feiferlíková, Romana - Bezděk, Jiří. 2013. Lidové písně z Plzeňska pro zpěv a klavír v úpravě Oldřicha Blechy. Plzeň: Vydavatelství M. Krist.

Gremlicová, Dorota. 2014. Tanec jako předmět literární debaty $v$ Čechách na konci 18. století. Živá hudba 5: 118-128. Hartl, Jiří Benedikt. [1810-1822]. Partibus pro Violin Prim für mich Georgius Hartl. Rkp. EÚ AV ČR, v. v. i., sign. 289/868-876. Holas, Čeněk. 1909. České národní písně a tance IV. Praha: B. Kočí. Holas, Čeněk. 1910. České národní písně a tance V-VI. Praha: B. Kočí. Janeček, Petr (ed.). 2011-2014. Staročeské pověsti, zpěvy, hry, obyčeje, slavnosti a nápěvy ohledem na bájesloví česko-slovanské, jež sebral Václav Krolmus I-III. Praha: Nakl. PLOT. Kazárová, Helena. 2005. Barokní taneční formy. Praha: AMU.
Langer, Josef Jaroslav. 1957. České prostonárodní obyčeje a písně. In: Bodláčí a růže. Výbor z díla. Praha: SNKLHU.

Markl, Jaroslav. 1987. Nejstarší sbírky českých lidových písní. Praha: Editio Supraphon.

Michal, Josef (ed.). 1959. Písně a tance $z$ Hradecka. Hradec Králové: Krajský dům osvěty.

Neruda, Jan. 1946. České národní tance. Praha: Nová osvěta.

Soukupová, Zora. 1980. Jihočeské tance II. České Budějovice: KKS.

Stavělová, Daniela. 1993. Rukopisný materiál J. E. Konopase jako významný pramen pro studium lidového tance kolem poloviny 19. století. Český lid 80: 321-334.

Stavělová, Daniela. 1996. Lidové tance $v$ guberniálním sběru z roku 1819. Praha: IPOS Artama.

Stavělová, Daniela. 2007. Minet. In: Lidová kultura. Národopisná encyklopedie Čech, Moravy a Slezska II. Praha: Mladá fronta: 561.

Stavělová, Daniela. 2008. Koncept národního tance: obkročák, polka, sousedská. In: Stavělová, Daniela Traxler, Jiří - Vejvoda, Zdeněk (eds.): Prostředí tance. Hranice identity a jejich překračování. Praha, NIPOS: 157-186. 
Suchý, František. 1955. Lidové písně a tance z Polabína Královéměstecku. Praha: SNKLHU.

Šebek, Svatopluk. 1959. Lidové písně a tance z Nymburska. Praha: Kabinet muzejní a vlastivědné práce Krajského domu osvěty.

Trojan, Jan. 1997. Menuet. In: Slovník české hudební kultury. Praha: Editio Supraphon: 547-548.

Tyllner, Lubomír (ed.). 1995. Böhmische Nationalgesänge und Tänze (České národní zpěvy a tance) gesammelt von T. A. Kunz I-II. Praha: ÚEF AV ČR.

Tyllner, Lubomír. 1997. Dvojí tendence $v$ tektonice českých lidových písní (příspěvek ke strukturální analýze českého písňového typu). Český lid 84: 265-274.

Vejvoda, Zdeněk. 2002. Tanec „do kolečka“ v dokumentech a ve sbírkách písní a tanců. Český lid 89: 15-30.

Vejvoda, Zdeněk. 2004a. Hudební typ objektivní východisko revize českého tanečně druhového systému. In: Stavělová, Daniela - Traxler, Jiří - Vejvoda, Zdeněk (eds.): Tanec - záznam, analýza, pojmy. Praha: Etnologický ústav AV ČR: 119-138.

Vejvoda, Zdeněk. 2004b. Nápěvy písní k tanci „do kolečka“ - analýza a hudební typ. Český lid 91: 153-203.

Vejvoda, Zdeněk. 2004c. Využití počítačové analýzy ve výzkumu českého písňového typu. In: Ethnomuzikologicum III. Bratislava: Ústav hudobnej vedy SAV: 177-197.
Vejvoda, Zdeněk. 2006. Nápěvy písní k tanci do kolečka - textová výstavba a deklamace. Český lid 93: 243-258.

Vejvoda, Zdeněk. 2008. Podoby lendleru v Čechách. In: Stavělová, Daniela Traxler, Jiří - Vejvoda, Zdeněk (eds.): Prostředí tance. Hranice identity a jejich překračování. Praha: NIPOS: 87-156.

Vejvoda, Zdeněk. 2012. Lendler v Čechách. Muzikologické fórum 1: 2: 61-67.

Vejvoda, Zdeněk. 2013. Hudební analýza. In: Thořová, Věra - Traxler, Jiří Vejvoda Zdeněk: Lidové písně z Prahy ve sbírce Františka Homolky II. Praha: Etnologický ústav AV ČR, v. v. i.: 80-112.

Vejvoda, Zdeněk. 2015. Hudební analýza podřipských písní. In: Thořová, Věra Traxler, Jiří - Tyllner, Lubomír - Vejvoda Zdeněk: Lidové písně z Podřipska ve sbírce Františka Homolky I. Studie I kritická edice. Praha: Etnologický ústav AV ČR, v. v. i.: 60-98.

Vetterl, Karel - Hrabalová, Olga (eds.). 1994. Guberniální sbírka písní a instrumentální hudby z Moravy a Slezska z roku 1819. Strážnice: Ústav lidové kultury.

Vycpálek, Josef. 1921. České tance. Praha: B. Kočí.

Weis, Karel. 1932. Český jih a Šumava v lidové písni VI. Praha.

Zemánek, Josef. 1912. Lidové tance z Chrudimska. In: Chrudimsko a Nasavrcko III. Chrudim: výbor ku popisu okresu Chrudimského a Nasavrckého.

Zíbrt, Čeněk. 1960. Jak se kdy v Čechách tancovalo. 2. vyd. Praha: SNKLHU. 